GRASAS Y ACEITES 66 (1)

January-March 2015, e060

ISSN-L: 0017-3495

doi: http://dx.doi.org/10.3989/gya.0689141

\title{
Analysis of agro-morphological diversity and oil content in Indian linseed germplasm
}

\author{
N. Dikshit ${ }^{\mathrm{a}, \bowtie}$ and N. Sivaraj ${ }^{\mathrm{b}}$ \\ ${ }^{a}$ National Bureau of Plant Genetic Resources, Regional Station, Dr. PDKV Campus, Akola-444104, Maharashtra, India \\ ${ }^{\mathrm{b}}$ National Bureau of Plant Genetic Resources, Regional Station, Hyderabad-500030, India \\ ${ }^{\bowtie}$ Corresponding author: dikshitn@gmail.com
}

Submitted: 02 June 2014; Accepted: 01 October 2014

\begin{abstract}
SUMMARY: One hundred and eleven accessions of linseed germplasm belonging to 32 districts of six states (Bihar, Chhattisgarh, Himachal Pradesh, Jharkhand, Madhya Pradesh and Maharashtra) in India were characterized for five qualitative and six quantitative traits. Significant variability was observed in the agro-morphological and qualitative traits. The Shannon diversity index varied from $0.23-0.70$ and the phenotypic coefficient of variation ranged from $6.0 \%$ to $37.1 \%$. IC 345425, an accession from Surgaon, Chandrapur, Maharashtra, was identified as promising for its high oil content $(41.5 \%)$. The Pearson correlation matrix generated for the quantitative traits indicated that positive and high correlation was observed among days to $50 \%$ flowering and days to $80 \%$ maturity $(0.9 ; \mathrm{P}$ value $<0.0001)$, plant height and seed weight $(0.7 ; \mathrm{P}$ value $<0.0001)$, seed weight and oil $\%$ (0.6; P value $<0.0001)$, seed weight and number of capsules per plant $(0.5$; P value $<0.0001)$. Two major clusters were formed when the characterization data was subjected to Ward's minimum variance method. DIVA-GIS approaches for the analysis of the diversity in linseed germplasm were mapped for quantitative traits such as plant height, number of capsules per plant and seed oil content.
\end{abstract}

\section{KEYWORDS: DIVA-GIS; Diversity; Flax; Germplasm; India-Linseed}

RESUMEN: Análisis de la diversidad morfológica y contenido de aceite del germoplasma de linaza india. Ciento once accesiones de germoplasma de semillas de lino pertenecientes a 32 distritos de seis estados de la India (Bihar, Chhattisgarh, Himachal Pradesh, Jharkhand, Madhya Pradesh y Maharashtra) se caracterizaron mediante cinco determinaciones cualitativas y seis cuantitativas. Se observó una variabilidad significativa tanto en los rasgos cualitativos como cuantitativos. El índice de diversidad de Shannon varió entre 0,23-0,70 y el coeficiente de variación fenotípica varió entre 6,0 y 37,1 \%. IC-345425, una accesión a partir Surgaon, Chandrapur, Maharashtra fue identificado como prometedora, por su alto contenido de aceite $(41,5 \%)$. La matriz de correlación de Pearson generado para los rasgos cuantitativos indicaron una correlación alta y positiva entre días a $50 \%$ de floración y días a $80 \%$ de maduración $(0,9$; valor $\mathrm{p}<0,0001)$, altura de planta y peso de la semilla $(0,7$; valor $\mathrm{p}<0,0001)$, peso de la semilla y porcentage de aceite $(0,6$; valor $\mathrm{p}<0,0001)$, peso de la semilla y número de cápsulas por planta $(0,5 ; \mathrm{P}$ valor $<0,0001)$. Cuando los datos de caracterización se sometieron al método de la varianza se formaron principalmente dos grupos Se intentaron planteamientos DIVA-GIS para el análisis de la diversidad de germoplasma de linaza que fueron mapeados y fueron asignados a rasgos cuantitativos como la altura de planta, el número de cápsulas por planta y contenido de aceite de las semillas.

PALABRAS CLAVE: DIVA- GIS; Diversidad; Germoplasma; Linaza; Semillas de lino India

Citation/Cómo citar este artículo: Dikshit N, Sivaraj N. 2015. Analysis of agro-morphological diversity and oil content in Indian linseed germplasm. Grasas Aceites 66 (1): e060. doi: http://dx.doi.org/10.3989/gya.0689141.

Copyright: (C) 2015 CSIC. This is an open-access article distributed under the terms of the Creative Commons Attribution-Non Commercial (by-nc) Spain 3.0 Licence. 


\section{INTRODUCTION}

Linseed, or flax (Linum usitatissimum L.), belongs to the family Linaceae under the genus Linum, and is reported to have about 100 species which are distributed globally. It has been under cultivation since ancient times for its fiber and seed. It occupies a prominent place among the oilseed crops owing to its various uses and special qualities. The seeds are a rich source of drying oil of edible nature and are the most potent source of omega-3 fatty acids, the desirable cholesterol for healthy living. Linseed contains about $26-45 \%$ oil. The oil is present mainly as triglycerides in oil bodies having an average diameter of 1.3 Micro m (Daun et al., 2003). Linseed oil is used in a wide variety of applications, including additives in PVC plastics, anti-rust agents, lacquers and paints, aroma substances for the food industry, etc. The DIVA-GIS is a Geographic Information System designed to assist in plant genetic resources (PGR) and biodiversity research communities to map the range of distribution of species of interest. It is particularly useful in elucidating the genetic, ecological and geographic patterns of the distribution of crops and wild species using locality (points) data available with gene banks, herbarium and natural history museum databases (Hijmans et al., 2001). The mapping could be extended to other related information on the material of interest, for example with respect to agronomic-traits in the present study. For a successful breeding programme, the identification of potential donor(s) for seed yield, oil yield combined with desirable agronomic and quality traits is a prerequisite. Hence, an attempt has been made to study the diversity in the linseed germplasm from 32 districts in India using DIVS-GIS approaches for morpho-agronomical characteristics and oil content and also to study the relationship among the accessions using cluster techniques.

\section{MATERIALS AND METHODS}

\subsection{Agro-morphological study}

In the present experiment, a set of 111 accessions of linseed germplasm collected from 32 districts of six states of India were used. State and districts Bihar (10), Jharkhand (9), Chhattisgarh (3), Madhya Pradesh (4), Maharashtra (4) and Himachal Pradesh (2). The germplasm were grown consecutively for two years $(2009-10 ; 2010-11)$ in the experimental farm of the National Bureau of Plant Genetic Resources Regional Station, Akola. An augmented block design was followed with each germplasm accession/variety in a row which was 3 meters wide row with $60 \mathrm{~cm}$ line spacing. RLC-6 and JC-23-10 were used as check varieties. The qualitative traits studied were early plant vigour, flower colour, flower shape, flower size, lodging tendency, seed size, seed luster, seed coat colour and quantitative traits were days to $50 \%$ flowering, number of capsules per plant, plant height $(\mathrm{cm})$, days to $80 \%$ maturity, weight of 100 seeds weight $(\mathrm{g})$ and seed oil content (\%). Standard minimal descriptors and descriptor states for linseed were followed for the agro-morphological study as prescribed by Mahajan et al., 2000.

\subsection{Oil analysis}

The seed oil content of linseed germplasm accessions was determined by a wide line nuclear magnetic resonance (NMR) method (Robertson and Morrison, 1979).

\subsection{Statistical analysis}

Statistical analyses on various agro-morphological traits were carried out. Frequency distribution and the Shannon Diversity Index were used to study qualitative traits and a descriptive Statistical Analysis including range, mean, standard deviation, standard error, kurtosis, sample variance, phenotypic coefficient of variation and multivariate analysis were carried out using the SAS enterprise guide 4.3 version.

\subsection{DIVA-GIS analysis}

DIVA-GIS version 7.5., an open source software programme downloaded from www.diva-gis.org was used for generating grid maps of diversity and statistics. Geographical coordinates of the collection sites from various parts of India were also obtained using the Garmin 12 Global Positioning System (GPS). The India shape file was used for plotting the geo referenced points using the layer menu on the software. The point-to-grid option using the 'simple' method on the "Analysis Menu" and the output variables "Diversity and Statistics" were selected for obtaining the output files. Under diversity, the Shannon diversity index was chosen and for the statistics, coefficient of variation was selected. Grid maps on the diversity and coefficient of variation were generated for select quantitative traits such as plant height, capsules per plant and oil content.

\section{RESULTS AND DISCUSSION}

\subsection{Agro-morphological characteristics and diversity of Indian linseed germplasm}

The linseed crop is known to have been cultivated for linseed or flaxseed since very ancient times and it is one of the oldest cultivated plants known to man. The one hundred and eleven linseed accessions characterized are found in six states of India viz., Bihar (25 accs.), Chhattisgarh (7 accs.), Himachal Pradesh 
(5 accs.), Jharkhand (29 accs.), Madhya Pradesh (11 accs.) and Maharashtra (34 accs.). These linseed accessions exhibited a wide range of variability with respect to morpho-agronomical traits. All the accessions showed good plant vigor. The flowers are mostly blue in color $(98.20 \%)$ with only $1.80 \%$ light blue. $73.87 \%$ are funnel-shaped followed by tubular $(20.72 \%)$ and disc-shaped $(5.41 \%)$. The size of the flowers varied from medium $(75.68 \%)$ to small $(24.32 \%)$. The seeds are brown in color in $93.69 \%$ of the cases and light brown in $6.31 \%$ of the cases. $80.18 \%$ are the intermediate type of seed luster followed by shiny (19.82\%). The Shannon Diversity Index ranged from $0.23-0.70$ and expressed diversity within the accessions studied (Table 1). Plant height ranged from $23.2 \mathrm{~cm}$ (IC 268339) to 45.9 $\mathrm{cm}$ (IC 345411). The number of capsules per plant varied from 26.6 (IC 320983) to 86.3 (IC 268350); days to $50 \%$ flowering ranged from 55.5 (IC 345409 , IC 345397) to 65.0 (IC 319837. IC 319845, IC 319846), days to maturity ranged from 89 days (IC 268349 ) to 121 (IC 319837); seed weight was (0.14 (IC 319846) to 0.91 (IC 345423); the oil content showed a range of $31.9 \%$ (IC 267682) to $41.5 \%$ (IC 345425) oil. Three other varieties/accessions with more than $41.0 \%$ oil were IC 345447 (41.4\%);
IC $345417(41.3 \%)$ and IC $345423(41.3 \%)$. A low coefficient of variation was observed in days to $80 \%$ maturity, oil (\%) and days to $50 \%$ flowering, along with moderate variation in plant height. 100-seed weight was found to have a high CV (37.10\%). IC 345425 , an accession collected from Surgaon village, Chandrapur, Maharashtra is identified as promising for oil content $(41.5 \%)$. It possesses medium seed weight $(0.65 \%), 60.3$ capsules per plant, plant height $(41.1 \mathrm{~cm})$, days to $50 \%$ flowering (58.5) and days to maturity (92 days). The wide range of variability observed in the present study is in accordance with the reports made by various earlier researchers in linseed viz., Mirza et al. (1996) for the number of capsules per plant and seed yield per plant; Mahto and Mahto (1998) for number of primary branches per plant, the number of secondary branches per plant, the number of capsules per plant and seed yield per plant; Chandrasekhar et al. (1998) for the number of capsules per plant and 1000-seed weight. Similarly, Mishra and Yadav (1999) reported a wide range of variability for the number of capsules per plant and seed yield per plant; Singh (1980) for the number of primary branches per plant, the number of secondary branches per plant and seed yield per plant. Muhammad Akbar et al. (2003) for plant

TABLE 1. Variability in agro-morphological and quality traits of linseed germplasm collected from India

\begin{tabular}{|c|c|c|c|c|c|}
\hline Qualitative traits/Descriptors & Descriptor states & Descriptor code & Frequency & Percent & SDI $^{*}$ \\
\hline \multirow[t]{2}{*}{ Flower color } & Light blue & 2 & 02 & 01.80 & 0.0902 \\
\hline & Blue & 3 & 109 & 98.20 & \\
\hline \multirow[t]{3}{*}{ Flower shape } & Tubular & 1 & 23 & 20.72 & 0.7075 \\
\hline & Funnel & 2 & 82 & 73.87 & \\
\hline & Disc shaped & 3 & 6 & 5.41 & \\
\hline \multirow[t]{2}{*}{ Flower size } & Small & 3 & 27 & 24.32 & 0.5547 \\
\hline & Medium & 5 & 84 & 75.68 & \\
\hline \multirow[t]{2}{*}{ Seed color } & Light brown & 3 & 7 & 6.31 & 0.2353 \\
\hline & Brown & 4 & 104 & 93.69 & \\
\hline \multirow[t]{2}{*}{ Seed luster } & Shiny & 1 & 22 & 19.82 & 0.4978 \\
\hline & Intermediate & 2 & 89 & 80.18 & \\
\hline Descriptive statistics & PLT_HGT & CAP_PLT & DAY_MAT & SED_WGT & OIL(\%) \\
\hline Minimum & 23.2 & 26.6 & 89.0 & 0.1 & 31.9 \\
\hline Maximum & 45.9 & 86.3 & 121.0 & 0.9 & 41.5 \\
\hline Range & 22.7 & 59.7 & 32.0 & 0.8 & 9.6 \\
\hline Mean & 34.1 & 48.0 & 95.7 & 0.4 & 36.9 \\
\hline Standard Error & 0.5 & 1.2 & 0.5 & 0.0 & 0.2 \\
\hline Standard Deviation & 5.4 & 12.7 & 5.7 & 0.2 & 2.4 \\
\hline Sample Variance & 28.9 & 161.8 & 33.1 & 0.0 & 5.8 \\
\hline Kurtosis & -0.9 & 0.2 & 11.4 & 1.3 & -0.7 \\
\hline Coefficient of Variation & 15.8 & 26.5 & 6.0 & 37.1 & 6.5 \\
\hline
\end{tabular}

"SDI- Shannon Diversity Index, PLT_HGT- Plant height (cm), CAP_PLT- Number of capsules per plant, DAY_MAT- Days to $80 \%$ maturity, SED_WGT- 100 -seed weight (g). 
height, number of capsules per plant, and 1000-seed weight. Ram et al. (2007) for the number of capsules per plant, Nagaraja et al. (2009) for seed yield per plant, Batta et al., (1985) and Bajpai et al., (1985) for oil content and fatty acid composition, Burako (2010) for oil yield and seed yield. Sivaraj et al. (2012) in a study of eighty four accessions of linseed germplasm of Andhra Pradesh and Maharashtra observed variability for agro-morphological, seed traits and fatty acid composition. Wide genetic diversity is a pre-requisite for the genetic improvement of any crop. The progress in developing a superior variety depends largely on the genetic basis of the selection of diverse parents and the breeding approach followed (Diedrichsen, 2001). However Linseed is the most neglected oilseed crop of developing countries and is grown on marginal land with poor management. A poor yield of this crop is attributed to the non-availability of improved cultivars to suit the diverse agro climatic conditions. Hence, the development of high yielding cultivars becomes the top priority to overcome the poor yield levels. The linseed accessions with high seed weight identified in this study may be used in breeding programmes aiming at producing lines with higher oil contents.

\subsection{Correlation studies of agro-morphological and quality traits}

The Pearson correlation matrix table for the quantitative traits studied on linseed germplam is provided in Table 2. A positive and high correlation was observed between days to $50 \%$ flowering and days to $80 \%$ maturity $(0.9 ; \mathrm{P}$ value $<0.0001)$, plant height and seed weight $(0.7 ; \mathrm{P}$ value $<0.0001)$, seed weight and oil $\%(0.6 ; \mathrm{P}$ value $<0.0001)$, seed weight and number of capsules per plant $(0.5$; $\mathrm{P}$ value $<0.0001)$. A medium correlation was observed between plant height and number of capsules per plant. A negative and low correlation was observed between plant height and days to maturity ( $\mathrm{P}$ value 0.02 ) and days to maturity and oil content ( $\mathrm{P}$ value 0.08 ). A negative but high correlation was observed between days to $50 \%$ flowering and 100 -seed weight ( $\mathrm{P}$ value $<0.0001$ ). Varshney et al., (1995) reported significant variability in yield-related characters in
36 linseed varieties/ lines for tillers, number of capsules and branches per plant. Knowledge about the association between yield and its attributes obtainable through the estimation of genotypic and phenotypic correlation helps a great deal to formulate selection strategies to develop suitable genotypes. A similar significant association of traits has also been observed by Kedarnath et al. (1960), Patil et al. (1989), Khorgade et al. (1992), Mirza et al. (1996), Kurt (1996), Mishra and Yadav (1999), Pal et al. (2000), Muhammed Akbar et al. (2003), Ram et al. (2007), Ramakant et al. (2008), Burako et al. (2010), Savita et al. (2011), Rahimi et al (2011) and Gauraha and Rao (2011). The study of the associations of yield components with yield assumes special importance and forms a basis for selecting desired strains. The breeder has to establish and understand the existing relationships between yield and yield attributing factors within a plant often arise because of either genetic linkage or pleiotropy (Herald, 1939).

\subsection{Multivariate Analysis}

Ward's method has been used to quantify the genetic divergence between the genotypes (hierarchial cluster analysis of linseed germplasm) and to identify diverse parents for crossing. It minimizes the total within-cluster variance. At each step the pair of clusters with minimum between-cluster distance is merged. To implement this method, at each step, the pair of clusters that leads to minimum increase in total within-cluster variance after merging must be found. This increase is a weighted squared distance between cluster centers. At the initial step, all clusters are singletons (clusters containing a single point). At the Euclidean distance (Semi-partial R-square) of 0.43 , the 111 accessions grouped into two major clusters with cluster I containing 90 accessions and the remaining 21 accessions along with two check varieties (RLC-6 and J-23-10) in Cluster II (Fig. 1). Both clusters are further divided into many sub-clusters. Interestingly, Cluster II consists of the majority of germplasm accessions (20) accessions collected from the Maharashtra state and only one accession,

TABLE 2. Correlation matrix for select quantitative traits in linseed germplasm

\begin{tabular}{lcccccc}
\hline & PLT_HGT & CAP_PLT & DAY_FLW & DAY_MAT & SED_WGT & OIL $\%$ \\
\hline PLT_HGT & 1.0 & & & & & \\
CAP_PLT & 0.4 & 1.0 & & & & \\
DAY_FLW & -0.5 & -0.5 & 1.0 & & & \\
DAY_MAT & -0.2 & -0.4 & 0.9 & 1.0 & & \\
SED_WGT & 0.7 & 0.5 & -0.6 & -0.5 & 1.0 & \\
OIL\% & 0.5 & 0.4 & -0.4 & -0.2 & 0.6 & 1.0 \\
\hline
\end{tabular}




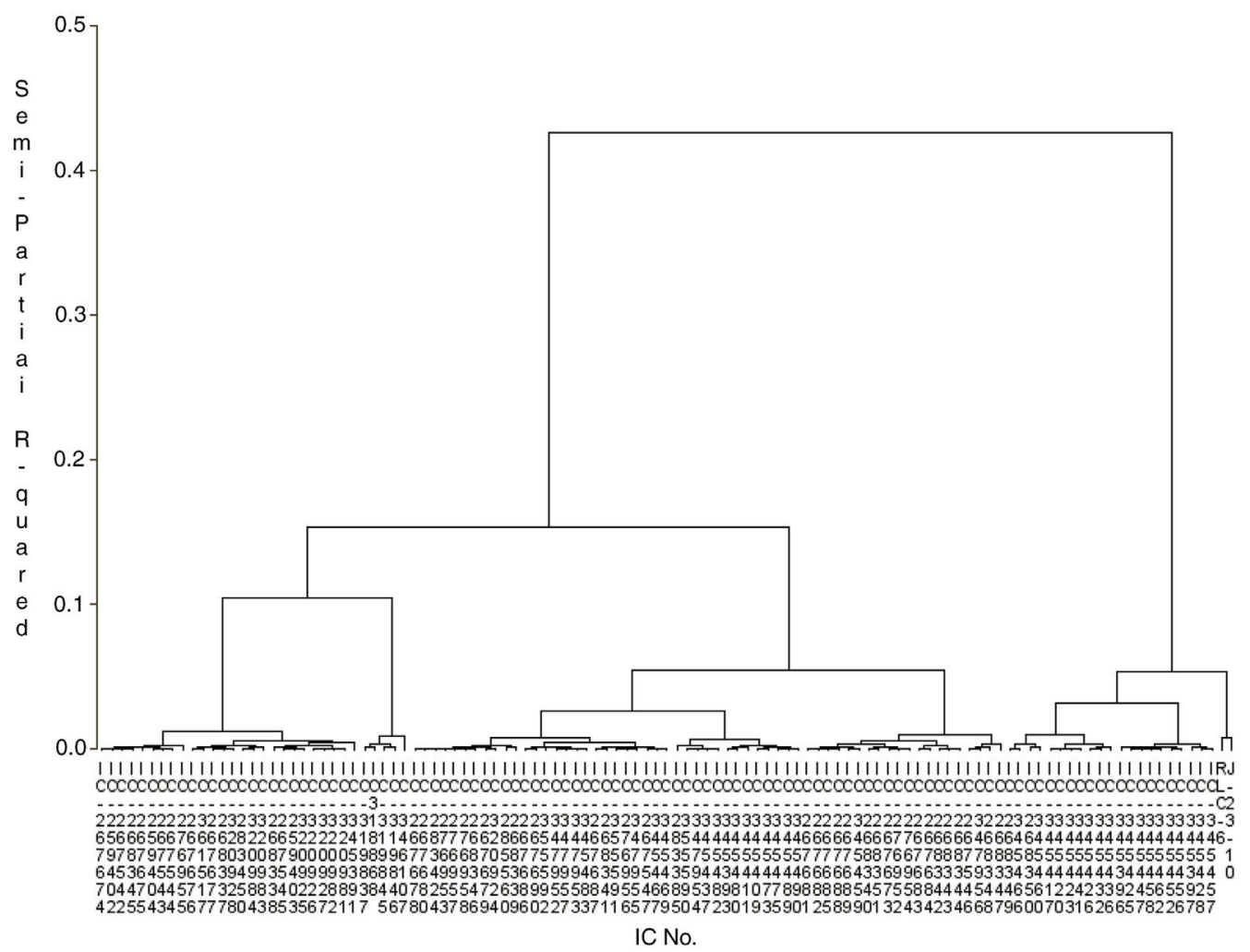

FIGURE 1. Ward's minimum variance dendrogram generated for linseed germplasm.

IC 268349, which was collected from Madhya Pradesh. Genetic divergence has been considered as an important factor in discriminating the genetically diverse parents for an efficient and successful hybridization programme in order to get potential transgressive segregants. The check varieties used in this study formed part of this cluster. The present investigation identified two major clusters and the magnitude of Euclidean values confirmed that there was a considerable amount of diversity in the experimental material of the linseed germplasm evaluated. The clustering pattern revealed a tendency for germplasm lines from diverse geographical regions to be grouped into one cluster and few accessions from same geographical region to enter into a separate group. These findings corroborated with the reports of Jeswani (1970), Asthana and Pandey (1980), Maharaddi (1996), Verma (1996), Pradhan et al., (1999), Ram et al., (2007) and Das (2000). The absence of a relationship between genetic diversity and geographical origin suggests a similarity in their genetic constitution and a free exchange of breeding material over places (Sharma, 2005). According to Dang et al. (1971) the clustering pattern could be utilized by choosing a parental combination for a prospective breeding programme to generate the highest possible variability in the yield components. Parents having high yield potential with wide genetic diversity are likely to yield superior segregants within a short period of time (Maurya and Singh, 1977).

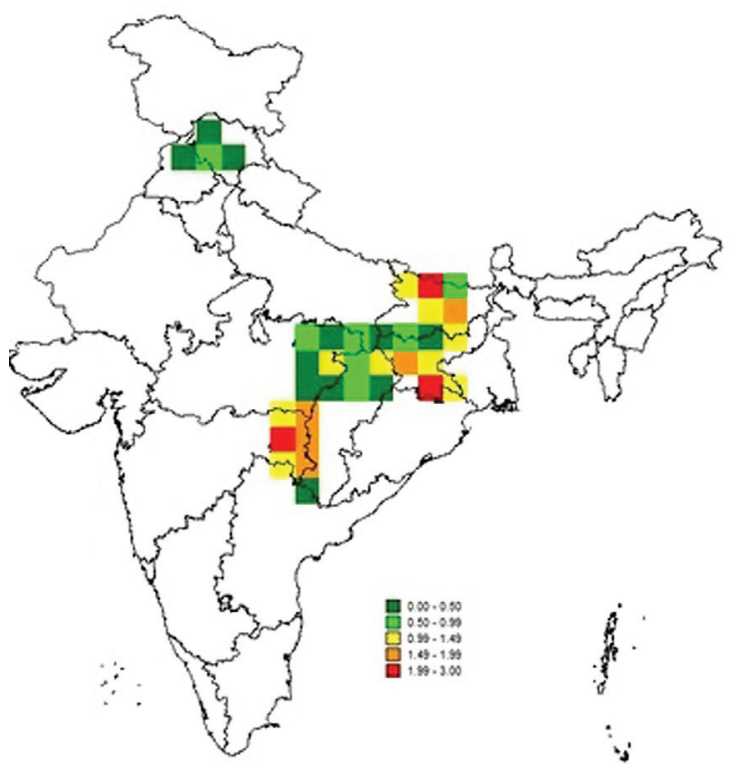

FIGURE 2. Grid map generated for the traits plant height, capsules per plant, oil content diversity in linseed germplasm. 


\subsection{DIVA-GIS analysis}

DIVA-GIS is particularly useful for mapping and analyzing biodiversity data, such as the distribution of species, or other 'point-distributions'. Locality data for the linseed germplasm accessions collected from six states of India were collected using a global positioning system. To study the spatial distribution and diversity analysis of select quantitative traits in linseed, a geographical information system has been used. To find regions that have high, low or complementary levels of diversity in the present study, grid maps were made using the DIVA-GIS computer program. Grid maps were generated for the diversity analysis and they indicated that diverse linseed germplasm accessions for plant height, capsules per plant and oil content were available in the Bihar, Jharkhand, Maharashtra states of India, where the highest Shannon diversity indices (1.99-3.0) were recorded for the traits plant height, capsules per plant and oil content, respectively (Fig. 2). The highest coefficient of variation for the trait plant height $(15-25 \%)$ recorded for the linseed accessions sourced came from the states of Bihar, Himachal Pradesh and Jharkhand (Fig. 3); and with respect to capsules per plant $(21-27 \%)$ for the Bihar, Jharkhand and Maharashtra accessions (Fig. 4). Interestingly, the highest $\mathrm{CV} \%$ for oil content was recorded only for the linseed accessions sourced from Himachal Pradesh (Fig. 5).

GIS mapping may be effectively used for documentation, diversity analysis, identifying gaps in collection, assessment of loss in diversity, developing new strategies for conservation, and sustainable utilization, particularly in the wake of recent international developments related to food and nutritional security. GIS mapping has been successfully used in assessing biodiversity and in identifying areas of high diversity in Phaseolus beans (Jones et al., 1997); wild potatoes (Hijmans et al., 2001); horsegram (Sunil et al., 2008); Jatropha curcas (Sunil et al., 2009); linseed (Sivaraj et al., 2012); blackgram (Abraham et al., 2010) and Canavalia fatty acids (Sivaraj et al., 2010).

\section{CONCLUSIONS}

Information about the nature and extent of genetic variability present in the germplasm collection and the association of various morphological characters is a pre-requisite to planning a successful breeding programme for the linseed crop. Further seed yield from linseeds is the sum of the effects of several yield component characteristics, which are governed by a large number of genes and also by environment. For a rational approach to the improvement of seed yield, selection has to be made for the components of yield. In our study of 111 accessions of linseed germplasm, significant diversity in morphological characteristics was observed among the accessions belonging to six different states of India. The Shannon diversity index ranged from $0.23-0.70$ and expressed diversity within the accessions studied. IC 345425 is identified as promising for oil content $(41.5 \%)$ as

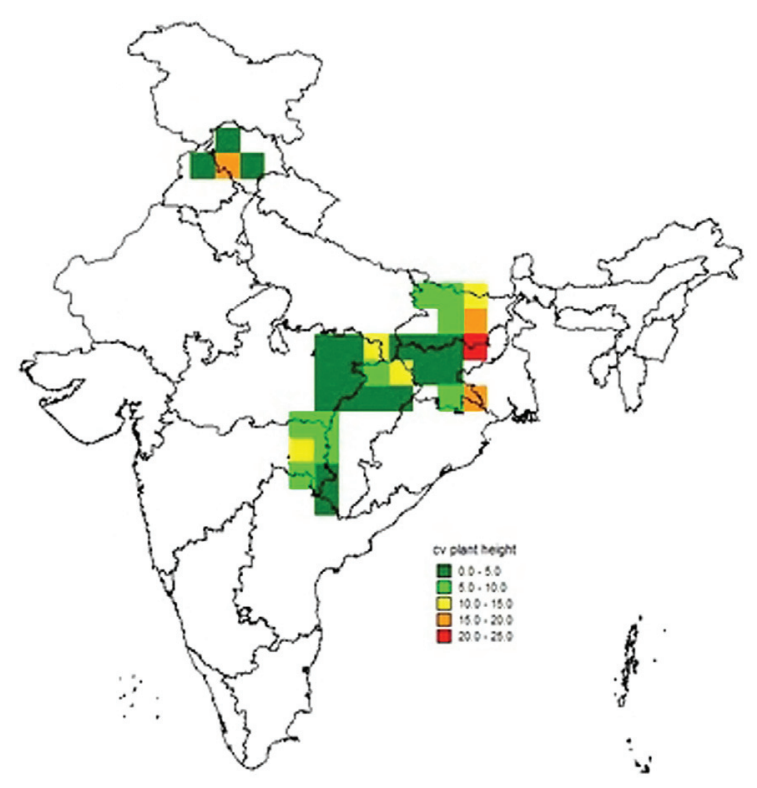

Figure 3. DIVA-GIS Grid map for the coefficient of variation in the trait plant height.

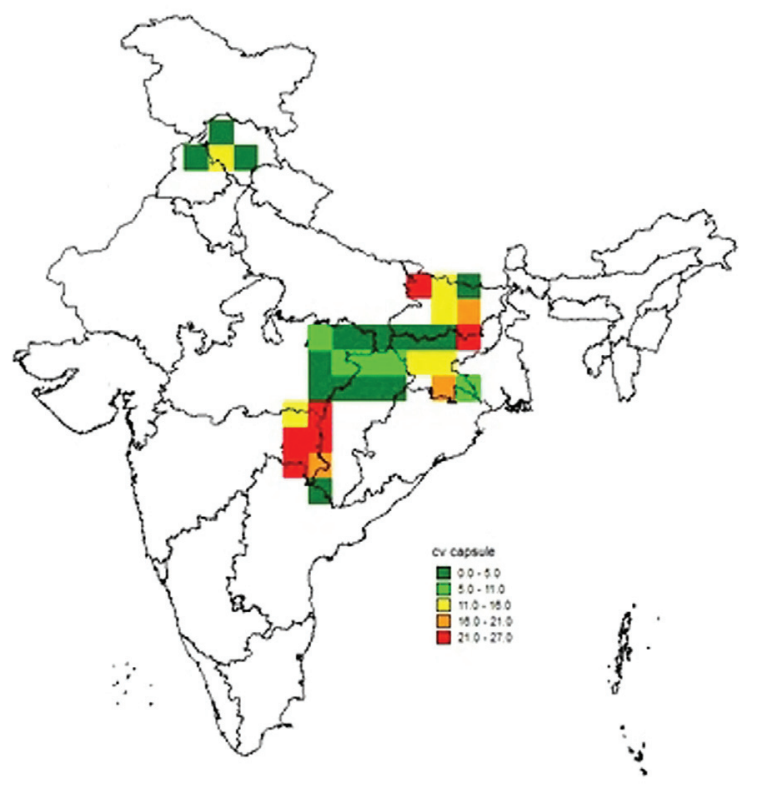

FIGURE 4. DIVA-GIS Grid map for coefficient of variation in the trait capsules per plant. 


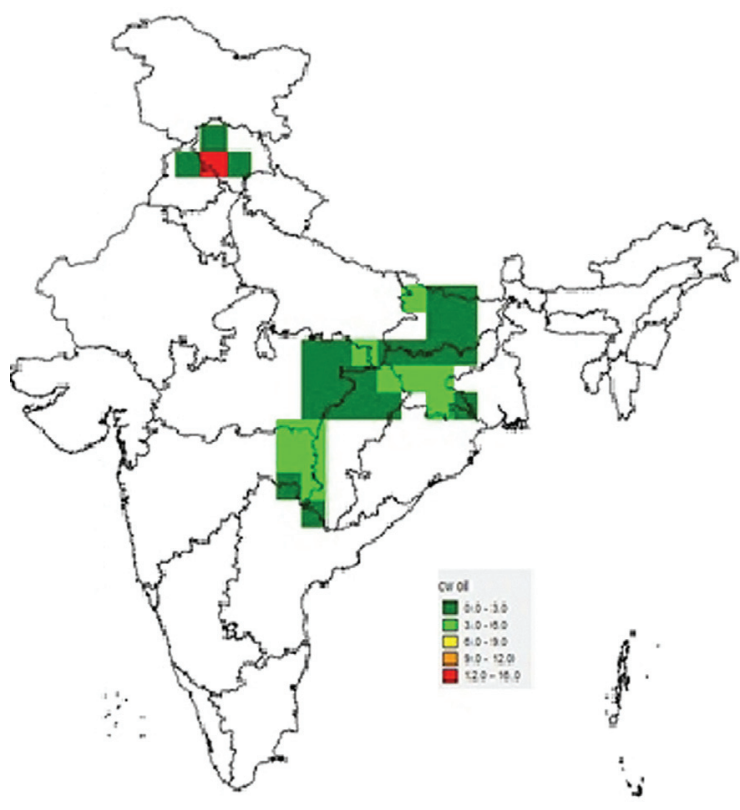

FIGURE 5. DIVA-GIS Grid map for coefficient of variation in the trait oil content.

it possesses medium seed weight $(0.65 \%), 60.3$ capsules per plant, plant height $(41.1 \mathrm{~cm})$, days to $50 \%$ flowering (58.5) and days to maturity (92 days). Three other accessions having more than $41.0 \%$ oils include IC 345447 (41.4\%), IC 345417 (41.3\%), IC $345423(41.3 \%)$. Genetic divergence has been considered as an important factor in discriminating the genetically diverse parents for an efficient and successful hybridization programme in order to obtain potential transgressive segregants. The genetic divergence studies identified two major clusters. The magnitude of the Euclidean values confirmed that there was a considerable amount of diversity in the linseed germplasm evaluated. The clustering pattern revealed a tendency of germplasm lines from diverse geographical regions to be grouped into one cluster and a few accessions from same geographical region entered into a separate group. DIVA-GIS mapping may be effectively used for documentation, diversity analysis, identifying gaps in collection, assessment of loss in diversity, developing new strategies for conservation, sustainable utilization, particularly in the wake of recent international developments related to food and nutritional safety.

\section{ACKNOWLEDGEMENTS}

The authors are thankful to the Director of the National Bureau of Plant Genetic Resources, New Delhi and to the Head of the Division of Germplasm Evaluation, NBPGR, New Delhi for facilities and help.

\section{REFERENCES}

Abraham B, Kamala V, Sivaraj N, Sunil N, Pandravada SR, Vanaja M, Varaprasad KS. 2010. DIVA-GIS approaches for diversity assessment of pod characteristics in black gram (Vigna mungo L. Hepper). Curr. Sci. 98, 616-619.

Asthana AN, Pandey VK. 1980. Genetic divergence in linseed. Indian J. Genet. 40, 247-250.

Bajpai A, Sharma M, Vashistha AK. 1985. Component acid and glycerides in the oil of different genetic varieties of linseed. J. Oil Technol. Assoc. India 17, 15-16.

Batta SK, Ahuja KI, Raheja RK, Labana KS. 1985. Variability in oil content and fatty acid composition in linseed (Linum usitatissimum L.). Ann. Biol. 1, 80-85.

Burako L. 2010. Genetic diversity study of linseed genotypes on acidic soil at bedi trial site, central highland of Ethiopia. M.Sc. Thesis, Dept. of Biology (Applied Genetics). Addis Ababa University.

Dang SS, Andani, Nasoeion AH. 1971. Multivariate classification of some rice (Oryza sativa L.) varieties and strains based on yield components. Rice News Letter 20, 26-34.

Das PN. 2000. Genetic divergence and selection of genotypes in soybean. J. Maharashtra Agric. Univ. 25, 250-252.

Daun JK, Barthet VJ, Chornick TL, Duguid S. 2003. In Flaxseed in human nutrition, second edition. AOCS Press, USA. $1-40$.

Diedrichsen A. 2001. Comparison of genetic diversity of flax (Linum usitatissimum L.) between Canadian cultivars and a world collection. Plant Breeding 120, 360-362. http:// dx.doi.org/10.1046/j.1439-0523.2001.00616.x.

Gauraha D, Rao SS. 2011. Association analysis for yield and its characters in Linseed (Linum usitatissimum L.). Research J. Agric. Sci. 2, 258-260.

Hearald SC. 1939. The Genetics of Cotton. Jonathan Capse, London.

Hijmans RJ, Garret KA, Huaman Z, Zhang DP, Schreuder $\mathrm{M}$, Bonierbale. 2001. Assessing the geographic representatives of genebank collections: the case of Bolivian wild potatoes. Cons. Biol. 14, 1755-1765. http://dx.doi.org/ 10.1111/j.1523-1739.2000.98543.x.

Jeswani LM, Murty BR, Mehra RB. 1970. Divergence in relation to geographical origin in a world collection of linseed. Indian J. Genet. 30, 11-25.

Jones PG, Beebe SE, Tohme J, Galway NW. 1997. The use of geographical information systems in biodiversity exploration and conservation. Biodiversity Cons. 6, 947-958.

Kedarnath S, Joshi AB, Batcha MGBR. 1960. Correlation studies in Linum usitatissimum II-Effect of morphological grouping of types on their correlation coefficients relating to yield and some of the components of yield. Indian $J$. Genet. Plant Breed. 20, 58-68.

Khorgade PW, Sakhare BA, Pillai B. 1992. Genetic parameters and character associations in linseed. Ann. Pl. Physiol. 6, 68-72.

Kurt O. 1996. Study on the yield and yield components and some agronomic characters of linseed cultivars. Ondokuzmayis Universitesi, Ziraat Fakultesi Dergisi. 11, 87-92.

Mahajan RK, Sapra RL, Umesh Srivastava, Mahendra Singh, Sharma GD. 2000. Minimal descriptors (for characterization and evaluation) of agri-horticultural crops (Part I). National Bureau of Plant Genetic Resources, New Delhi.

Maharaddi KN. 1966. Nature of genetic divergence in soybean (Glycine $\max (\mathrm{L}$.)Merrill). M. Sc. (Agri.) Thesis, University of Agricultural Sciences, Dharwad.

Mahto RN, Mahto JL. 1998. Variability, correlation and path co-efficient analysis in linseed. J. Res. Birsa Agri. Univ. 10, 25-29.

Maurya DM, Singh DP. 1977. Genetic divergence in rice. Indian J. Genet. Plant Breed. 37, 395-402.

Mirza, SH, Nessa D, Islam S. 1996. Genetic studies of interrelationship between seed yield and its components in linseed. Bangladesh J. Bot. 25, 197-201.

Mishra AK, Yadav LN. 1999. Genetic parameters and association analysis in Linseed. Ind. Jour. Agri. Res. 33, 113-118.

Muhammad Akbar, Tariq Mahmood, Anwar M, Muhammad Ali, Muhammad Shafiq, Jaffar Salim. 2003. Linseed 
improvement through genetic variability, correlation and path coefficient analysis. Int. J. Agric. Biol. 5, 303-305.

Nagaraja TE, Ajit KR, Golasangi BS. 2009. Genetic variability, correlation and path analysis in linseed. J. Maharashtra Agri. Univ. 34, 282-285.

Pal SS, Gupta TR, Singh I. 2000. Genetic determination of yield in linseed (Linum usitatissimum L.). Crop Improv. 27, 109-110.

Patil RR, Sinha MN, Rai RK, Prasad M. 1989. Correlation and regression analysis in linseed (Linum usitatissimum). Indian J. Agric. Sci. 59, 598-599.

Pradhan B, Mishra A, Mishra PK. 1999. Genetic variability in linseed (Linum usitatissimum L.). Indian J. Agric. Sci. 69 , 281-282.

Rahimi MM, Zarei MA, Arminian A. 2011. Selection criteria of flax (Linum usitatissimum L.) for seed yield, yield components and biochemical compositions under various planting dates and nitrogen. African J. Agric. Res. 6, 3167-3175.

Ram K, Srivastava RK, Singh P. 2007. Selection criteria and screening of elite germplasm lines of linseed. Int. J. Plant Sci. 3, 439-442.

Rama Kant, Chauhan MP, Srivastava RK, Maurya KN. 2008. Correlation and path coefficient analysis of seed yield and yield components of linseed (Linum usitatissimum L.). Int. J. Plant Sci. 3, 323-325.

Robertson JA, Morrison WH. 1979. Analysis of oil content of sunflower seed by wide-line NMR. J. Am. Oil Chem. Soc. 56, 961-964.

Savita SG, Kenchanagouda PV, Parameshwarappa KG, Rudranaik V. 2011. Correlation and path coefficient analysis for yield and yield components in linseed (Linum usitatissimum L.) germplasm. Karnataka J. Agric. Sci., 24, 382-386.
Sharma SS. 2005. Genetic divergence in Indian varieties of soybean. Soybean Res. 3, 9-16.

Singh KN. 1980. Path analysis in linseed under sodic soil condition. Indian J. Genet. Plant Br. 40, 385-387.

Sivaraj N, Sunil N, Pandravada SR, Kamala V, Rao BVSK, Prasad RBN, Nayar ER, Joseph John K, Abraham Z, Varaprasad KS. 2010. Fatty acid composition in seeds of Jack bean [Canavalia ensiformis (L.) DC] and Sword bean [Canavalia gladiata Jacq.) DC] germplasm from South India: A DIVA-GIS analysis. Seed Technol. 32, 46-53.

Sivaraj N, Sunil N, Pandravada SR, Kamala V, Babu Abraham, Vinod Kumar, Rao BVSK, Prasad RBN,Varaprasad KS. 2012. Variability in linseed (Linum usitatissimum L.) germplasm collections from peninsular India with special reference to seed traits and fatty acid composition. Indian $J$. Agric. Sci. 82, 102-105.

Sunil N, Sivaraj N, Pandravada SR, Kamala V, Raghuram Reddy P, Varaprasad KS. 2008. Genetic and geographical divergence in horsegram germplasm from Andhra Pradesh, India. Plant Genet. Resour. Characterization and Utilization 7, 84-87. http://dx.doi.org/10.1017/S1479262108019801.

Sunil N, Sivaraj N, Anitha K, Babu Abraham, Vinod Kumar, Sudhir E, Vanaja M, Varaprasad KS. 2009. Analysis of diversity and distribution of Jatropha curcas L. germplasm using Geographic Information System (DIVA-GIS). Genet. Resour. Crop Evol. 56, 115-119. http://dx.doi.org/10.1007/ s10722-008-9350-x.

Varshney SK, Sah JN, Singh ON. 1995. Variability and correlation in linseed. J. Oilseed Res. 12, 17-19.

Verma OP. 1996. Genetic divergence in linseed (Linum usitatissimum L.). J. Oilseed Res. 13, 225-228. 